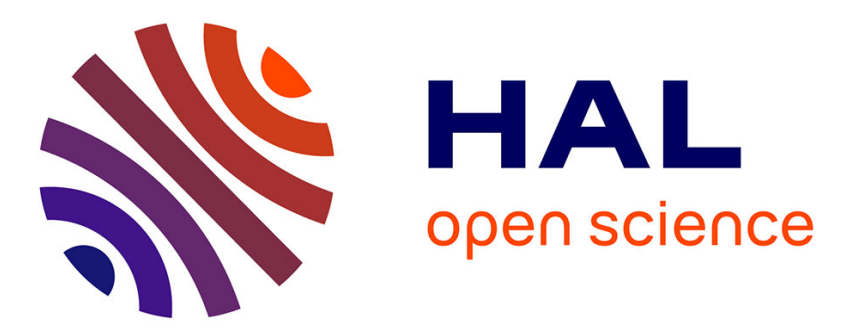

\title{
Turning the gender tables: evidence of students' awareness of a reversal in gender status between academic and occupational contexts
}

Alyson Sicard, Delphine Martinot, Marie-Christine Toczek, Julie Pironom, Céline Darnon

\section{To cite this version:}

Alyson Sicard, Delphine Martinot, Marie-Christine Toczek, Julie Pironom, Céline Darnon. Turning the gender tables: evidence of students' awareness of a reversal in gender status between academic and occupational contexts. Social Psychology of Education, 2021, 24 (1), pp.247-272. 10.1007/s11218021-09607-0 . hal-03400173

\section{HAL Id: hal-03400173 \\ https://hal.science/hal-03400173}

Submitted on 25 Oct 2021

HAL is a multi-disciplinary open access archive for the deposit and dissemination of scientific research documents, whether they are published or not. The documents may come from teaching and research institutions in France or abroad, or from public or private research centers.
L'archive ouverte pluridisciplinaire HAL, est destinée au dépôt et à la diffusion de documents scientifiques de niveau recherche, publiés ou non, émanant des établissements d'enseignement et de recherche français ou étrangers, des laboratoires publics ou privés. 


\title{
Turning the gender tables : evidence of students' awareness of a reversal in gender status between academic and occupational contexts
}

\author{
Alyson Sicard ${ }^{1 *}$, Delphine Martinot ${ }^{1 *}$, Marie-Christine Toczek², Julie Pironom², Céline \\ Darnon $^{1}$
}

${ }^{1}$ Université Clermont Auvergne, CNRS, LAPSCO, F-63000 Clermont-Ferrand, France.

${ }^{2}$ Université Clermont Auvergne, Laboratoire ACTé, F-63000 Clermont-Ferrand, France.

* corresponding authors: alyson.sicard@uca.fr, delphine.martinot@uca.fr

\section{ORCID-ID}
Alyson Sicard (D) https://orcid.org/0000-0003-1631-5034
Delphine Martinot (1) https://orcid.org/0000-0001-7216-9209
Marie-Christine Toczek (D) https://orcid.org/0000-0002-0301-4753
Céline Darnon (1) https://orcid.org/0000-0003-2613-689X

\section{Acknowledgments}

This research was supported by the French region Auvergne Rhone Alpes (INEGS project). We extend our gratitude to the schools, the teachers and the university professors who agreed to cooperate with us in the conduct of this study. 


\begin{abstract}
This study investigates young people's awareness of gender differences in achievement and their reversal between educational and occupational contexts. Girls are generally more academically successful than boys but men still enjoy a superior position in the professional world. The present study therefore aimed to determine whether students were aware of a reversal in gender gap, and to explore whether the characteristics associated with high and low status groups (competence and warmth) are attributed to boys and girls in a way that is consistent with their perceived achievementrelated status. From sixth grade to bachelor's degree level, 638 students (347 girls and 290 boys, $\left.M_{a g e}=15.98\right)$ rated boys' and girls' academic status in middle school, high school and university, as well as men's and women's occupational status. They also assessed male and female students' warmth and competence at their respective school levels. Overall, participants seemed to be aware of a reversal in gender status between educational contexts, where they attributed the highest status to girls, and the occupational context, in which men were perceived as having the highest status. The youngest students have a limited awareness of gender inequalities in the professional world suggesting that understanding of gender dynamics increases with age. Furthermore, female students were perceived as more competent but not necessarily warmer than male students, suggesting they might be considered as a non-traditional female subgroup. This set of perceptions might have different, yet important, implications for boys' and girls' educational and occupational experience and the maintenance of gender hierarchy.
\end{abstract}

Key words: gender gap; awareness of gender inequalities, academic and occupational contexts, competence, adolescence. 


\section{Turning the gender tables : evidence of students' awareness of a reversal in gender status between academic and occupational contexts}

\section{Introduction}

For several years, international studies and reports have shown that girls outperform boys in educational settings (OECD 2015; Voyer and Voyer 2014), whereas traditional gender inequalities persist in the professional world. Indeed, women are, for instance, still underrepresented in the highest positions (WEF 2017). Gender gaps in achievement therefore appear to reverse between academic and occupational (i.e., related to the work area) contexts, with girls generally doing better than boys at school and men being more successful than women in the professional world. The aim in the present study is twofold. First, we aim to test whether young people are aware of these gender gaps in achievement and their reversal between academic and occupational contexts. Second, we examine whether the characteristics generally used to describe the high and low status groups are attributed to boys and girls in a way that is consistent with the perceived achievement-related status of gender groups at their respective school levels.

\subsection{Gender gaps in achievement}

Education and work represent two important life areas in which achievement is highly valued. Academic achievement is often perceived as one of the determinants of future success in life, particularly in terms of occupational success. Most of the students involved in the Programme for International Student Assessment (PISA) think that trying hard at school will help them get a good job (94\%) and that school has taught them things which could be useful in a job (91\%) (OECD 2013). However, the gender differences in achievement reported in the educational and occupational contexts seem to be in opposite directions so that the most occupationally successful group is not necessarily the most academically successful one.

Several surveys demonstrate that, even if some progress has been made towards gender equality, large discrepancies persist in the occupational context (European Institute for Gender Equality 2017). According to The World's Women 2015, a United Nations report, women across the globe still earn between $70 \%$ and $90 \%$ of what men earn. Wage gaps occur in most countries, including the most developed nations, and can start early in the career path (United Nations 2015). In France, where the present study was conducted, women's salaries are around 200 euros lower than men's, only 30 months after graduating (DEPP 2018). In addition, to this day, women are still underrepresented in top positions. Indeed, only $4 \%$ of chief executive officers (CEOs) in the world's largest 500 companies are women (United Nations 2015). Women, unlike men, usually head towards occupations associated with low pay and low status, such as social work 
(European Institute for Gender Equality 2017). Thus, gender hierarchy in the professional world seems to be characterized by a strong male dominance over women (Bourdieu 1998).

On the contrary, studies suggest that girls generally outperform boys in educational context, leading a growing amount of research to focus on boys difficulties since the 1990's (Weaver-Hightower 2003). Girls appear to have better grades than boys, not only in reading and writing but also in mathematics and science (Kenney-Benson et al. 2006; OECD 2015; Pomerantz et al. 2002; Voyer and Voyer 2014). In France, girls currently achieve higher success rates than boys in all the national exams, regardless of the options (sciences, technology, literature, etc.) (DEPP 2018). Moreover, across OECD (Organization for Economic Cooperation and Development) countries, boys are more likely than girls to repeat a grade (OECD 2015). They are also more likely than girls are to drop out of school and leave secondary education without a diploma (EURYDICE 2010; McFarland et al. 2018). Even though many indicators of academic achievement in secondary education favor girls, gender differences in academic performance can vary depending on the academic domain or the indicator considered. More precisely, girls' advantage appears to be stronger in the verbal domain and on grades as opposed to the scientific domain and performances on standardized tests respectively (Buchmann et al. 2008; Duckworth and Seligman 2006). Concerning higher education, numerous reports show that female students are underrepresented in Science, Technology, Engineering, and Mathematics (STEM) fields and instead head for less prestigious fields, such as education or health (EURYDICE 2010; Fiske 2012; European Institute for Gender Equality 2017). However, regardless of study fields, more women than men enter higher education in almost all OECD countries (OECD 2017). According to the UNESCO World Atlas of Gender Equality in Education (2017), women represent the majority of students in most countries (Fiske 2012). Besides being more numerous, women also appear to be more successful. In Europe, where women represent around $55 \%$ of students, they obtain $59 \%$ of degrees (EURYDICE 2010). On average, French women leave higher education with higher degrees than men (DEPP 2018). Therefore, when it comes to academic achievement in higher education, girls could also be considered more successful than boys.

To sum up, there is a reversal in the observed gender gap between the educational context, associated with girls' academic superiority, and the occupational context (i.e., related to the work area), in which men achieve better than women. The first objective of the present study is to determine whether young people, from early adolescence (11-12 years old) to the beginning of adulthood (around 20 years old), are aware of this reversal in gender inequalities.

\subsection{Young people's awareness of the gender gaps}

Gender is a relatively visible social identity whose related categories are acquired early in life. Between the ages of 2 and 3 years old, children know the gender group to which they and others belong (Martin and Ruble 2010) and their 
knowledge and understanding of gender dynamics in society seem to increase as they get older. Even though several studies have investigated young people's awareness of gender inequalities, research has focused on either the occupational domain or the educational domain (Heyder and Kessels 2013; Neff et al. 2007), without investigating these two domains simultaneously. Therefore, we will review the literature regarding each of these domains, starting with the occupational domain.

Studies suggest that young people are aware that men tend to occupy the highest positions in the occupational context. For instance, Teig and Susskind (2008) showed that young people from 6 to 12 years old associated stereotypically feminine jobs (e.g., nanny) with lower status (assessed in terms of difficulty, importance and money) than masculine jobs (e.g., soldier), causing these feminine jobs to be underrepresented among the highest status occupations (Teig and Susskind 2008). Similarly, Liben, Bigler and Krogh (2001) demonstrated that young people rated familiar masculine jobs (e.g., business executive) as higher in status than familiar feminine jobs (e.g., secretary). However, these differences were smaller in children (6-8 years old) than in early adolescents (11-12 years old) who, contrary to their younger peers, also associated unfamiliar jobs portrayed with male workers with a higher status than unfamiliar jobs portrayed with female workers (Liben et al. 2001). Such findings suggest that awareness of gender inequalities increases with age. Consistent with this idea, Neff, Cooper, and Woodruff (2007) showed that a majority of young people from 7 to 12 years old think that men and women have equal status in the spheres of business and politics, whereas adolescents and young adults (from 12 to 20 years old) become increasingly aware of male dominance. Literature therefore suggests that, at least from early adolescence, young people are aware that men enjoy higher occupational status than women.

In comparison to the amount of research conducted on the perception of gender groups' status in the professional world, few studies have directly examined the awareness of a gender gap in academic achievement. Some studies, however, suggest that students believe in girls' academic superiority (Hartley and Sutton 2013; Latsch and Hannover 2014). For instance, Hartley and Sutton (2013) showed that starting in Year 3 (7-8 years old), both boys and girls believe in girls' academic superiority and think that adults share their beliefs. Students' perceptions of girls' academic superiority appeared to increase with age, particularly among boys. Similarly, on an implicit association task, ninth graders seem to associate school with girls more strongly than they associated it with boys (Heyder and Kessels 2013). However, this effect was based primarily on the associations reported by girls, suggesting that boys might not strongly hold such implicit beliefs. When assessing stereotypes regarding specific academic domains, Martinot, Bagès and Désert (2012) demonstrated that children might hold different beliefs about gender differences in academic achievement depending on target's age. Even though they were aware of a gender stereotype favoring male adults in mathematics, they believed that young female and 
male students were equally successful in this domain. In the verbal domain, they reported a stereotype in favor of both women and girls (Martinot et al. 2012). Thus, young people might be aware of girls' academic superiority.

Literature regarding young people's awareness of the gender gaps in academic or occupational achievement suggest they might be aware that, on the one hand, girls are generally more academically successful than boys and that, on the other hand, men enjoy higher occupational status than women. Awareness of gender dynamics seems to increase, as they get older. However, as mentioned above, it remains unclear whether young people are aware of the reversal in gender gap between academic and occupational contexts. We would like to address this issue by examining their perception of gender groups' achievement-related status in these two domains, within the same study. Indeed, in line with Tajfel and Turner (1979) and Sachdev and Bourhis (1987) who define group status as "the relative position of groups on valued dimensions of comparison such as educational achievement or occupation", we postulate that girls' higher relative position on the dimension of academic achievement will bring them a higher academic (or scholastic) status than boys on this dimension. Conversely, men will have a higher occupational status than women on the dimension of work achievement. The present study therefore aims to examine gender groups' status in academic and occupational contexts to determine whether students, in accordance with gender gaps in achievement, are aware of the reversal of boys' and girls' status between these two contexts.

\subsection{Perception of male and female students' characteristics}

The second objective of the present study is to investigate students' perceptions of boys' and girls' characteristics in the educational context. With such an analysis, we would explore which perception of gender hierarchy they support. Even though girls should be perceived as having a higher academic status than boys because of their academic superiority, they nevertheless experience difficulties at school that are associated with a disadvantaged group (sexism, sexual harassment, segregation in school playground, ...) (Leaper and Brown 2014). Moreover, students' perception of boys' and girls' intelligence at school seems more favorable to boys than to girls. Indeed, girls' intelligence is perceived as more effort-based and related to poorer potential to succeed in the future than boys' intelligence (Verniers and Martinot 2015a). Verniers, Martinot and Dompnier (2016) also showed that academically successful girls are perceived as more compliant and less assertive than successful boys, which seems to be consistent with a traditional and stereotypical gender perspective. Therefore, in addition to the assessment of boys' and girls' status on the dimension of academic achievement, we will explore which group is ascribed the characteristics of a high-status group in the academic context. 
The Stereotype Content Model, developed by Fiske and her colleagues (Fiske et al. 2002), posits that characteristics ascribed to different groups are determined by the structural relations between groups. Group status is, for instance, related to perceived competence in that the higher the group status, the more competent its group members are perceived to be (Cuddy et al. 2009). Competence is usually associated with warmth, as they represent together the two universal and fundamental dimensions of social judgment, according to which most groups can be described (Cuddy et al. 2008). Several studies demonstrated that people usually hold ambivalent beliefs towards social groups and tend to compensate in intergroup ratings (Cuddy et al. 2008; Eckes 2002; Fiske et al. 2002; Kervyn et al. 2010; Yzerbyt et al. 2005). Compensation is defined as "social perceivers tendency to differentiate between two social targets in a comparative context on the two fundamental dimensions of social judgement by contrasting them in a negative direction" (Kervyn et al. 2010). Thus, if one gender group is considered as more competent than the other, it may, however, be perceived as less warm than the other gender group. For instance, men are usually regarded as quite competent but not highly warm whereas women are described as rather warm but not necessarily competent (Fiske et al. 2002). Little is known, however, about how female and male students are perceived on the competence and warmth dimensions, as most studies have focused on boys' and girls' perceived abilities in different academic domains (e.g., mathematics, reading, science).

If girls' higher academic achievement is associated to the attribution of a higher academic status to their group, they should be perceived as more competent, and by compensation less warm, than boys at school. Some studies nevertheless suggest it might not actually be the case. Indeed, girls are the primary target of sexism in academic context (Leaper and Brown 2014). The majority of adolescent girls interviewed in Leaper and Brown's (2008) study reported hearing at least once discouraging statements about their abilities at school. Moreover, girls are underrepresented in fields believed to require brilliance, assertiveness, intelligence or effort but are more numerous in fields requiring compliance (Aelenei et al. 2019; Meyer et al. 2015; Verniers and Martinot 2015b). Consequently, it is also likely that, despite their higher academic achievement, girls would be perceived as less competent, and by compensation warmer, than boys in the academic context. Such description of male and female students would be consistent with the gender stereotype associated to traditional male and female groups. Indeed, research shows that traditional women (e.g., housewives, typical women) are described as highly warm but not necessarily competent whereas traditional men (e.g., manager, typical man) are perceived to be competent but not warm (Cuddy et al. 2008; Eckes 2002). However, a recent study conducted by Eagly, Nater, Miller, Kaufmann and Sczesny (2019) suggests that gender stereotypes targeting adults might have changed over time in so that women would be perceived as more competent than they were before. The present study therefore aims to 
examine among young people how male and female students are perceived in terms of warmth and competence, in order to explore which gender group is associated with the characteristics of a high-status group.

\subsection{Hypothesis}

The present study deals with young people's beliefs regarding two specific contexts that are academic and occupational (i.e., work) contexts and pursues two main objectives. First, it aims to investigate whether young people are aware of the gender gaps in achievement and their reversal between academic and occupational contexts. It appeared that awareness of gender inequalities in these two contexts have never been assessed within the same study. Based on research focusing on either the occupational or the academic domain, we hypothesize that young people are aware of the reversal in gender status. More precisely, girls' status on the dimension of academic achievement should be perceived as higher than that of boys and, on the contrary, men should be considered as having a higher status than women on the dimension of work achievement. Second, we intend to examine young people's perception of male and female students' characteristics to determine whether being perceived as the high-status group in terms of academic achievement gives female students the characteristics of a high-status group in the academic context. If academic achievement ascribed a high-status to girls, we hypothesize that female students will be described as more competent but less warm than male students, because of the people's tendency to compensate.

\section{Method}

\subsection{Participants}

The participants were 638 French students from sixth grade to the second year of bachelor's degree. The sample comprised 347 girls and 290 boys (one participant did not report their gender) whose ages ranged from 10 to 27 years old $(M=15.98, S D=3.44$; see Table 1 for more details). The middle-school and high-school students were enrolled in the general education curriculum. More precisely, twelfth-grade students were enrolled in a science option, which is, according to an annual report published by the French Ministry of Education, the most gender-balanced option that French general education offers in the last two years of high school (DEPP 2018). We recruited undergraduate students from two distinct study fields: biology $(n=89)$, and Sciences and Techniques of Physical and Sport Activities, which we will refer to as sports $(\mathrm{n}=112)$. In France, the former is a rather "feminine" study field ( $61 \%$ female students), whereas the latter can be considered as a male-dominated field (71\% male students) (MESRI 2018). Written informed consent was obtained for all participants who volunteered to take part in the study and written parental consent was also required for students under 18 years old. Authorizations from school directors and teachers, as well as ethical approvals from French Committee for 
Persons Protection (2017 / CE 29; \# IRB00008526), were provided. Before conducting the present study, we used G Power to carry out a-priori power analysis based on the effect size obtained in a preliminary study $\left(\eta_{p}^{2}=.090\right)$. This analysis suggested that at least 68 participants for each school level were required to obtain the expected interaction between the target group and target context with a 0.80 power. As presented in Table 1, the present study has at least 100 participant per school level.

\section{INSERT TABLE 1}

\subsection{Procedure}

The research was presented as a study on students' perception of school (or university for the university students). Along with their classmates, the participants completed a questionnaire starting with the assessment of the status of the male and female groups. They were randomly assigned to one of the two conditions, depending on the target group they had to judge (female vs. male group). Approximately half of the participants assessed the female group's status while the other half assessed the male group's status. Each participant had to indicate the extent to which they believed that the male (female) group had a high status in four different contexts: middle school, high school, university, and the professional world. Thus, the experimental design consisted in a mixed 2 (participants' gender: male vs. female) X 4 (target context: middle school, high school, university and professional world, within-participant) X 2 (target group: female vs. male group, between-participants) X 5 (participants' school level: sixth vs. eighth vs. tenth vs. twelfth grade vs. second year of bachelor's degree, between-participants) design. The participants then reported their perception of boys' or girls' warmth and competence at their school level (i.e., middle school, high school, or university). Finally, they completed sociodemographic measures such as their gender, age, school level and parents' highest academic qualification.

\subsection{Measures}

\subsubsection{Perception of context-specific status}

Based on Tajfel and Turner's (1979) as well as Sachdev and Bourhis's (1987) definitions of group status, we assessed gender groups' achievement-related status in academic and occupational contexts by examining their relative position on an important dimension of comparison in each of these domains. In the educational context, academic achievement depends mainly on grades, which appears to be a central dimension of comparison in this context. As students are often selected on the basis on their grades, good grades make academically successful students freer to choose the courses or the fields they want, enable them to access prestigious courses or fields of study, and help them obtain higher qualifications and merits. For young people, an equivalent basis of achievement in the occupational context might be 
income, which is used for the assessment of occupational status by children and adolescents as it is a relatively tangible and easily understandable concept (Liben et al. 2001). Moreover, as income and educational attainment are two of the three main indicators of social status (Kraus and Stephens 2012), school grades and income should represent relevant indicators of group status. To operationalize our measure of the perceived status of female and male groups, we designed ladders based on the ones created by Sweeting, West, Young, and Kelly (2011) to measure adolescents' subjective social status. Three ladders represented the target group (boys' vs. girls' group) in middle school, high school and university respectively, and a fourth ladder represented the target group (men vs. women group) in the occupational context. The top of the ladders represented the most successful people. Regarding the academic context, academically successful students were described as those achieving the best grades in class and the best results in exams. The participants were asked how academically successful they thought boys [girls] were at the three levels of the school curriculum (middle school, high school and university). For each level, they had to position the boys [girls] group on one of the rungs of the corresponding ladder. Concerning the occupational context, the top of the ladders represented the most successful people, defined as those earning the more money. The participants had to rate how successful they thought men or women were in the occupational context by positioning their target group (men vs. women) on one of the rungs on the ladder.

\subsubsection{Perceived characteristics in the educational context}

The participants assessed, at their respective school levels (i.e., middle school, high school or university), the extent to which they thought that boys or girls are warm and competent (Cuddy et al. 2008). In the same way as for the perception of status, half of the participants assessed the characteristics of the boys' group, whereas the other half assessed those of the girls' group. Four items referred to competence (competent, confident, skillful and able; $\alpha=.54$ ). The item "confident" was removed from the analysis because it reduced the reliability of the scale $\left(\alpha_{\text {corrected }}=.68\right)$. Four items appraised warmth (warm, nice, friendly and sincere; $\alpha=.82$ ). The participants rated either boys or girls at their school level on each trait using a scale from 1 (Not at all) to 7 (Very much) which was presented in the form of a barometer.

\section{Results}

\subsection{Preliminary analyses}

As the participants were nested within different classes, we conducted preliminary analyses to determine whether multi-level analyses were required. We ran unconditional means models and computed intraclass correlations (ICCs) to assess the proportion of variance between classes for each tested model (status, characteristics). As ICCs were relatively 
small $\left(\mathrm{ICC}_{\text {status }}=0.009 ; \mathrm{ICC}_{\text {characteristics }}=0.019\right)$ and none of the random intercepts reached significance $(p>.10, n s)$, we conducted single-level analysis.

\subsection{Main analyses}

\subsubsection{Perceived status}

To assess the evolution of the perceived status associated with the male and female groups, we conducted an analysis of variance (ANOVA) with the target context (middle school, high school, university and professional world) as a within-participant variable. The participants' gender (male vs. female), the target group (female vs. male group) and school level (sixth vs. eighth vs. tenth vs. twelfth grade vs. bachelor's degree) were included as between-participants factors. As Mauchly's test indicated a violation of the assumption of sphericity, $\chi^{2}(5)=140.63, p<.001$, GreenhouseGeisser corrected tests are reported $(\varepsilon=0.89)$. All pairwise comparisons were computed using Bonferonni correction to account for multiple comparisons.

The analysis revealed a main effect of target group such that, overall, the participants attributed a higher status to the female group $(M=7.62, S E=0.06)$ than to the male group $(M=7.19, S E=0.06), F(1,607)=27.01, p<.001, \eta_{p}^{2}=$ .043. There was also a main effect of target context, $F(2.65,1611.07)=8.15, p<.001, \eta_{p}{ }^{2}=.013$. Pairwise comparisons showed that, regardless of the target group, the participants attributed a lower status to the high-school targets than to the middle-school $(p<.001)$, university $(p=.018)$ and professional world targets $(p=.002)$. These effects were qualified by a significant interaction between the two variables, $F(2.65,1611.07)=72.85, p<.001, \eta_{p}{ }^{2}=.107$. The simple-effects analysis revealed that the participants attributed a higher status to the girls' group than to the boys' group in the educational contexts, that is in middle school, high school and university $\left(F_{\text {middle }}\right.$ school $(1,607)=60.73, p<.001, \eta_{p}^{2}=.091, F_{\text {high }}$ school $(1,607)=$ $\left.68.20, p<.001, \eta_{p}^{2}=.101, F_{\text {university }}(1,607)=34.36, p<.001, \eta_{p}{ }^{2}=.054\right)$. Conversely, they assessed the status of the men group as being higher than that of the women group in the professional world, $F_{\text {professional world }}(1,607)=43.60, p<.001, \eta_{p}^{2}$ $=.067$, which is consistent with the awareness of a reversal of gender gap between academic and occupational contexts. This interaction was associated with a second-order interaction between the target group, target context and participants' gender, $F(2.65,1611.07)=11.86, p<.001, \eta_{p}{ }^{2}=.019$. Both female and male students' ratings followed the previously described pattern. As illustrated in Fig 1, they only differed in the amplitude of perceived status differences.

\section{[INSERT FIG 1]}


The results also revealed a main effect of participants' school level, $F(4,607)=3.67, p=.006, \eta_{p}^{2}=.024$. Pairwise comparisons showed that, while other differences were not significant $(p>.10, n s)$, undergraduate students tended to attribute lower status than sixth-grade $(p=.037)$ and tenth-grade students $(p=.063)$. This main effect was associated with a significant interaction with participants' gender, $F(4,607)=2.82, p=.024, \eta_{p}{ }^{2}=.018$. The simple-effect analysis only revealed significant gender differences for undergraduate students, with female undergraduates attributing higher status than male undergraduates, $F(1,607)=8.94, p=.003, \eta_{p}{ }^{2}=.015$. The results also showed a significant interaction between participants' school level and target context, $F(10.62,1611.07)=6.13, p<.001, \eta_{p}^{2}=.039$, which was associated with a second-order interaction with the target group, $F(10.62,1611.07)=5.97, p<.001, \eta_{p}{ }^{2}=.038$. Estimated means and test statistics for the simple effects are reported in Table 2. It appeared that, overall, all participants attributed a higher status to the girls' group than the boys' group in the middle-school, high-school and university contexts (see Table 2). Regarding the occupational context, participants from eighth grade to bachelor's degree perceived men's status as higher than that of women. Contrary to the older participants, the sixth graders attributed a higher occupational status to the women group, which suggests that they might not be aware of the traditional gender inequalities in the professional world. Finally, the results revealed a significant third-order interaction involving all the predictors, $F(10.62,1611.07)=1.95, p=.032, \eta_{p}^{2}=$ .013. Simple effects are reported in Table 3. Overall, male and female participants' ratings at the different school levels followed the previously described pattern. The main differences were that, compared to their female peers, male students were less likely to acknowledge girls' academic superiority, particularly in middle school (see S1 for a graphic representation). Undergraduate male students, for instance, did not report significant status difference in middle school and high school, $p>.10, n s$. Conversely, female students were less likely than male students to perceive significant status differences in university (see Table 3).

\section{INSERT TABLES 2 AND 3}

In line with our prediction regarding the awareness of the reversal of the gender inequalities, participants from eighth grade to bachelor's degree attributed a higher status to the girls' group than to the boys' group in academic contexts and, conversely, rated the status of the men group as higher than that of the women group in the occupational context. Sixth graders, however, attributed higher status to girls and women in both contexts, suggesting limited awareness of gender inequalities in occupational context. As our university subsample comprises students from two different study fields (biology and sports), we conducted additional analyses to examine it more precisely. 


\section{RUNNING HEAD: STUDENTS’ AWARENESS OF A REVERSAL IN GENDER STATUS}

We conducted an analysis of variance (ANOVA) only among undergraduate students with the target context (middle school, high school, university, and professional world) as a within-participant variable. The participants' gender (male vs. female), the target group (female vs. male group) and study field (biology vs. sports) were included as betweenparticipants factors. As Mauchly's test indicated a violation of the assumption of sphericity, $\chi^{2}(5)=80.90, p<.001$, Greenhouse-Geisser corrected tests are reported $(\varepsilon=0.80)$.

The analysis revealed a main effect of the target group such that, overall, the status of the female group $(M=7.58$, $S E=0.09)$ was perceived as higher than that of the male group $(M=6.97, S E=0.09), F(1,190)=23.91, p<.001, \eta_{p}^{2}=$ .112. There was also a main effect of participants' gender showing that, regardless of the target group, the female students attributed a higher status than the male students, $F(1,190)=7.89, p=.006, \eta_{p}^{2}=.040$. These effects were associated with a second-order interaction between the target group, the participants' gender and the study field, $F(1,190)=6.63, p=.011$, $\eta_{p}{ }^{2}=.034$. The results showed that, unlike the other participants, the male sports students did not perceive any overall significant status differences between the male and female groups, $F<1, p>.10, n s$. The analysis also revealed a main effect of target context, $F(2.41,458.35)=8.67, p<.001, \eta_{p}^{2}=.044$. Overall, pairwise comparisons showed that the participants attributed lower status as the target was older. There was also a significant interaction between the target group and the target context, $F(2.41,458.35)=41.85, p<.001, \eta_{p}{ }^{2}=.180$. The undergraduate students rated girls' status as higher than boys' status in the three educational contexts, $F_{\text {middle school }}(1,190)=28.87, p<.001, \eta_{p}^{2}=.132 ; F_{\text {high school }}(1,190)=$ $29.82, p<.001, \eta_{p}{ }^{2}=.136 ; F_{\text {university }}(1,190)=54.64, p<.001, \eta_{p}{ }^{2}=.223$. They also perceived that men have the highest status in the professional world, $F_{\text {professional world }}(1,190)=25.27, p<.001, \eta_{p}{ }^{2}=.117$. These effects were associated with two second-order interactions. The first interaction involved the target group, the target context and the participants' study field, $F(2.41,458.35)=4.40, p=.008, \eta_{p}^{2}=.023$. The simple-effects analysis revealed that, even if both the sports and biology students' ratings followed the previously described pattern, they differed in the amplitude of perceived status differences (see Table 4). More precisely, biology students tended to report larger status differences than sports students between the male and female groups in the middle-school, high-school and occupational contexts, whereas in the university context, by contrast, sports students seemed to perceive larger status differences than biology students. Finally, the second interaction effect was between the target group, the target context and the participants' gender, $F(2.41,458.35)=7.26, p<.001, \eta_{p}^{2}=$ .037. Although female undergraduates' perceptions of status followed the previously described pattern, male undergraduates' perceptions were different. Indeed, male undergraduates did not perceive significant status differences between the boys' and girls' groups in the middle-school and high-school contexts, $p_{s}>.10$, ns. However, they rated the status of the girls group as the highest in the university context, $F_{\text {university }}(1,190)=24.48, p<.001, \eta_{p}{ }^{2}=.114$, and, 
conversely, perceived the status of the men group as being higher than that of the women group in the occupational context,

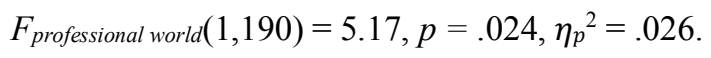

\section{INSERT TABLE 4}

Although all the undergraduate students were aware of a reversal in gender gaps between university and occupational contexts, male and female undergraduates reported different perceptions of the target groups' status in the context of secondary education. Indeed, unlike the female undergraduates, the male undergraduates did not attribute the highest status to girls in the middle-school and high-school contexts. Yet, biology and sports undergraduate students seemed to have similar perception of gender group status and their reversal.

\subsubsection{Perceived characteristics in the educational context}

To determine how participants perceived male and female students in terms of competence and warmth, the participants were asked to assess the extent to which they think that boys or girls are warm and competent at their school level (i.e., middle school, high school or university). We conducted a 2 (characteristics: competence and warmth, withinparticipant) x 2 (participants' gender: male vs. female) x 2 (target group: male vs. female group, between-participants) x 5 (participants' school level: sixth grade vs. eighth grade vs. tenth grade vs. twelfth grade vs. bachelor's degree, betweenparticipants) ANOVA on the overall sample. The analysis revealed a main effect of the characteristic assessed, with the participants rating the target $(M=5.56, S E=0.03)$ as more competent than warm $(M=4.61, S E=0.04), F(1,610)=543.78$, $p<.001, \eta_{p}^{2}=.471$. This main effect was qualified by three second-order interactions. First, there was a significant interaction between the characteristics and participants' gender, $F(1,610)=6.49, p=.011, \eta_{p}{ }^{2}=.011$. It appeared that, even if both male and female participants perceived the target as more competent than warm, differences are larger among female participants $\left(F(1,610)=373.90, p<.001, \eta_{p}{ }^{2}=.380\right)$ compared to their male counterparts $(F(1,610)=191.18, p<$ $\left..001, \eta_{p}{ }^{2}=.242\right)$. Second, the results showed a significant interaction between the characteristics and participants' school level, $F(4,610)=6.13, p<.001, \eta_{p}^{2}=.039$. Again, participants consistently perceived the target as more competent than warm. However, unlike competence, they perceived the target as warmer as they are older, $F(4,610)=6.35, p<.001, \eta_{p}^{2}$ $=.040$. Third, the analysis revealed a significant interaction between the characteristics and the target group, $F(1,610)=$ $16.34, p<.001, \eta_{p}{ }^{2}=.026$. Both boys' and girls' groups were perceived as more competent $\left(M_{\text {girls }}=5.87, S E=0.05\right.$; $\left.M_{\text {boys }}=5.25, S E=0.05\right)$ than warm $\left(M_{\text {girls }}=4.76, S E=0.06 ; M_{\text {boys }}=4.46, S E=0.06\right)$ but girls' group was described as more competent and warmer than boys' group, $F_{\text {competence }}(1,610)=87.23, p<.001, \eta_{p}^{2}=.125 ; F_{\text {warmth }}(1,610)=11.16, p=.001$, $\eta_{p}{ }^{2}=.018$. 
Results also showed a significant second order interaction between the characteristics, target group and participants' school level, $F(4,610)=6.63, p<.001, \eta_{p}{ }^{2}=.042$. Simple-effects analysis revealed that the girls' group was perceived as more competent than the boys' group in middle school, high school and university (see Table 5). Participants also rated the girls' group as warmer than the boys' group in middle school, but the two groups were evaluated as equally warm in high school and university (see Table 5).

\section{INSERT TABLE 5}

This interaction was qualified by a third-order interaction between the characteristics, target group, participants' gender and participants' school level, $F(4,610)=2.67, p=.031, \eta_{p}{ }^{2}=.017$. Male and female participants appeared to have different perceptions of the gender groups' characteristics depending on their school level (see Figs 2a and 2b). Simpleeffects analysis showed that male participants perceived that the girls' and the boys' groups are equally competent in middle school, $p_{s}>.10, n s$. They rated the girls' group as more competent than the boys' group in high school and university, even though the differences were only marginal for tenth graders (see Table 2a). Male sixth and twelfth graders also rated the girls' group as warmer than the boys' group in middle school and high school, respectively. However, male undergraduates perceived the boys' group as warmer than girls' group in university (see Fig 2a). Regarding female participants, simpleeffects analysis revealed that they perceived the girls' group as more competent than the boys' group in middle school, high school, and university. Female participants rated girls' and boys' groups as equally warm in high school, whereas the girls' group was perceived as warmer in middle school and university (see Fig 2b). Overall, students rated girls as more competent than (or at least as competent as) boys at their respective school levels. Even though the perceptions regarding the gender groups' warmth varied greatly across school levels, girls were more likely to be perceived as warmer than boys in the educational context. However, because they were also perceived as more competent than warm, female students did not seem to be in line with traditional gender stereotypes related to social judgment.

$$
\text { [INSERT FIG 2a] }
$$

$$
\text { [INSERT FIG 2b] }
$$

\subsection{Exploratory analysis}

Finally, we computed the correlations between the different dependent variables that are the (academic and occupational) status and the characteristics in the educational context, for each of the target groups. The objective was to examine, on the one hand, the perceived relationship between educational and occupational status and, on the other hand, 
the link between academic status and perceived characteristics. Correlations are reported in Table 6 . They seem to differ greatly depending on the target group. Boys' perceived status in middle school is positively correlated to their high-school status $(r=.40)$, which is related to both university $(r=.36)$ and occupational $(r=.24)$ status. For the girls' groups, all perceived statuses are correlated to one another and the observed correlations are larger than the one reported for boys' group (except for the correlation between university and occupational status). Interestingly, inconsistent with the notion of ambivalent beliefs developed in the literature, competence and warm are positively correlated, for both boys $(r=.42)$ and girls $(r=.52)$ groups. These two characteristics, even though they were measured in the educational context, are not significantly correlated with boys' academic status but appear to be (weakly) related to their occupational status (see Table 6). On the contrary, girls' characteristics seem to primarily relate to their academic rather than occupational status. The higher their academic status, the more competent and the warmer girls were perceived to be (see Table 6).

\section{INSERT TABLE 6}

\section{Discussion}

In the academic context, girls outperform boys on many indicators (OECD 2015), but women still earn less money than men in the professional world (WEF 2017). The literature on young people's perception of gender inequalities suggests that they might be aware of men's favorable position in the occupational context and, less clearly, of girls' academic superiority. Some ambiguity remained regarding whether young people perceive a reversal in the gender achievement gap between the educational and occupational contexts, especially because no study has so far examined these two domains simultaneously. The present study is therefore the first to examine the awareness of gender inequalities in both contexts, considering different stages of education (middle school, high school, university). To do so, we questioned young people - from early adolescents to young adults - on their perception of gender differences in achievement. We hypothesized that young people would be aware of a reversal in gender groups' status. In other words, they would attribute a higher status to girls compared to boys in the educational context and conversely rate men's occupational status as higher than that of women. The present findings supported this hypothesis. Overall, both female and male participants rated the status of the girls' group as higher than that of the boys' group in educational contexts (from middle school to higher education), which matches the reality of gender differences in academic achievement in France, as well as in most industrialized countries (DEPP 2018; Voyer and Voyer 2014). These results are also consistent with previous studies highlighting the existence of gender stereotypes favoring girls at school (Latsch and Hannover 2014; Martinot et al. 2012). With regard to the occupational context, all but the youngest participants (i.e., sixth graders) attributed the highest status to the men group 
based on the amount of money they earn. Again, these results reflect the gender pay gap observed in most nations around the world (United Nations 2015; WEF 2017). Interestingly, sixth graders did not share the same perceptions as older participants concerning gender gaps in the professional world. They attributed the highest status in the occupational context to women, in line with their ratings of boys' and girls' status in the educational contexts. As suggested by Liben, Bigler and Krogh (2001), even though children attributed a higher status to traditionally masculine jobs (e.g., engineer) compared to feminine jobs (e.g., nurse), they might not, at that age, understand the meaning of these differences in occupational status for the gender hierarchy. Understanding of gender dynamics increases with age, so that, by mid-adolescence (i.e., eight grade), participants seem to be aware of the existence of two opposing achievement gaps: one favorable to girls in the educational context and one favorable to men in the professional world. Our findings suggest that young people might first develop their awareness of gender inequalities in the educational context, which is more familiar to them, and later become aware of a reversed gender gap in the occupational context.

The present findings also revealed some differences between boys and girls in their perception of gender inequalities. First, even though they attributed a higher status to girls than to boys in the middle-school and high-school contexts, female participants were more likely than their male peers to attribute similar status to the gender groups in the university context. These findings suggest that, even if both female and male students perceive the existence of a reversal in gender gaps between academic and occupational contexts, female students tend to anticipate this reversal. Second, unlike the female undergraduates, male undergraduate students did not perceive any difference in status between girls and boys when their ratings focused on secondary education (middle school and high school). However, they considered that girls had the highest status in the university context. More generally, it appears that male participants are more reluctant to acknowledge girls' academic superiority in secondary education, and particularly in middle school. The absence of recognition of the superiority of girls' status in secondary education might facilitate the justification of men's domination in the professional world by removing a paradox. Illustrating the process of injunctification, Kay et al. (2009) showed that, when people are motivated to justify the status quo, they adapt their perceptions of women in a way that fits with the status quo (Kay et al. 2009). For example, individuals who have been led to believe that there are few women in politics perceive women as less ideal and less desirable members of parliament compared to those who believed that many women are active in politics. We therefore suggest that their motivation to justify men's dominance in society might lead male students to see girls as being less academically successful than they actually are. However, the process of injunctification does not explain why the male undergraduates attributed the highest status to girls in the university context rather than denying girls' academic superiority, as they did in the case of secondary education. Injunctification might not be strong enough to make 
this gender gap, which university students witness daily, disappear. Besides, the fact that female students did not report an academic superiority of girls in the university context could also help justify a reversed gender gap in society as it removes part of the paradox. Indeed, it becomes easier to justify men's dominance in society if girls are no longer perceived as outperforming boys in university. If so, the present findings might illustrate two different strategies male and female students could use to justify the system. Future studies need to test these assumptions regarding the role of system justification in explaining these results.

The second original feature of the present study was to investigate students' perceptions of boys' and girls' characteristics (competence and warmth) in the educational context to determine whether they corresponded with the relative position of gender groups on the dimension of academic achievement (i.e., their academic status). Derived from the Stereotype Content Model (Fiske et al. 2002), girls, insofar as they are perceived as a high-status group on the dimension of academic achievement, would be more competent but less warm than boys. Overall, results revealed that girls are perceived as more competent but also warmer than boys in academic context. Participants ascribed to girls both competence, the characteristic of high status groups, and warm, which is usually attributed to low-status group to compensate for their relative lack of competence (Cambon et al. 2015). Therefore, participants' ratings are inconsistent with the assumption that people usually hold ambivalent beliefs towards social groups (Cuddy et al. 2008). Male undergraduates, in rating boys as warmer and less competent than girls in university are the only ones to show a clear compensation pattern. The absence of a compensation effect might be related to at least two factors. First, compensation is more likely to occur when participants have the opportunity to rate both groups on the two dimensions (Kervyn et al. 2010). In the present study, the participants only rated the characteristics of one of the two groups. Second, Cambon, Yzerbyt, and Yakimova (2015) demonstrated that people tend to rely on compensation primarily when the distance between the groups is large and appears as legitimate and stable (Cambon et al. 2015). As most students perceived a reversal in gender status between academic and occupational contexts, differences in the status of the gender groups might have been perceived as unstable and somewhat illegitimate, thus creating conditions in which compensation is less likely to occur. In order to test this assumption, it would have been necessary to include a measure of the perceived stability and legitimacy of the gender hierarchy.

Male and female participants seem to hold different beliefs regarding the characteristics associated with boys and girls in the educational context. In line with their perception of gender gap in achievement, female students consistently rated girls as the most competent group, at all school levels. By contrast, male students' beliefs varied across school levels. They perceived boys as competent as girls in middle school but less competent than girls in high school and university, 
which is consistent with their perceived gender gap. In an attempt to better understand the underlying processes, we explored the correlations between the different measures. Results showed that participants perceived girls' academic status in secondary education (middle school and high school) to be more strongly related to the occupational status than that of boys. These findings are consistent with the PISA report which showed that boys were more likely than girls to think that school did little to prepare them for their adult life (OECD 2015). However, participants thought boys' academic status in university as more strongly related to their occupational status than that of girls. These results are consistent with the idea that girls' occupational success is more likely to depend on factors other than their achievement in higher education (e.g., innate traits, their wish to have children). Therefore, the relationship between academic achievement and occupational success seem more complex than we assumed and might be different for boys and girls. Exploratory analysis also revealed that, contrary to girls, boys' academic status was perceived as unrelated to their competence in that same domain. Their academic competence was, however, seen as related to their occupational status. Such results suggest that students have a different representation of boys' and girls' competence in academic context. Consistent with our findings, research demonstrated that, even though academically successful girls could be described as more intelligent and hardworking than academically successful boys (Verniers et al. 2016), their intelligence is perceived as less malleable than that of boys (Verniers and Martinot 2015a). Therefore, even if the results of the present study suggest students are aware that girls are more academically successful than boys, girls do not seem to be considered as possessing the characteristics of a highstatus group in that context. The acknowledgement of their achievement appears to be strictly related to academic achievement, which seems weakly correlated with occupational success and might be related to stereotypical attributions.

This set of results lead to consider that female students could belong to a specific female subgroup. Several studies have shown that there are subgroups of men and women and the traits assigned to these subgroups depend on whether or not they respect traditional gender roles (Cuddy et al. 2008; Eckes 2002; Glick and Fiske 2001). On the one hand, traditional women (e.g., housewives) are usually associated with paternalistic beliefs, portraying them as highly warm but relatively incompetent. On the other hand, non-traditional women (e.g., businesswomen) are perceived as cold but competent (Cuddy et al. 2008; Eckes 2002). Participants' description of female students as more competent than warm seems more consistent with the image of a non-traditional rather than traditional subgroup, which therefore suggests that female students might be considered as non-traditional women. Considering female students, whose academic superiority seem to be acknowledged by students, as a non-traditional subgroup might in fact help to remove the paradox induced by the reversal of gender status between academic and occupational contexts. The academic competence of female students can explain their academic achievement, but, as female students represent a non-traditional subgroup, they might be considered, like 
feminist or businesswomen, as one of the "exceptions" of the general female group. Competence would then be restricted to some subgroups and their corresponding domain (academic competence for female students or business competence for businesswomen), without being characteristic of the superordinate group. This way, female students' academic achievement appears as less conflicting with women inferior position in the professional world. However, another explanation is that gender stereotypes might have changed over time in so that women would be perceived as more competent than they were before (Eagly et al., 2019). The results of Eagly et al.'s study, which gathers US opinion polls from 1946 to 2018, shows that nowadays the majority of respondents thinks that women and men are equally competent. It is therefore possible that girls' academic achievement has directly or indirectly (through the opportunities offered by higher education) improved women's general reputation in terms of competence. Yet, in this study (Eagly et al., 2019), men appeared to still be perceived as more agentic and less communal than women. Thus, even though gender stereotypes might have changed over time on the competence dimension (i.e., possession of skills), they seem to remain relatively stable concerning the agency dimension (i.e., taking effective actions) (Eagly et al. 2019). Thus, to test whether female students truly represent a non-traditional subgroup of women, future studies will have to examine whether girls' academic achievement might (or might not) influence both competence and agency people assign to them.

\subsection{Limitations and Perspectives}

A first limitation of this study is its cross-sectional design. We measured perceived gender inequalities among different students at different school levels to examine their awareness of gender inequalities. This design allowed us to question students from sixth grade to bachelor's degree level in a relatively short amount of time, thus enabling us to work with a representative sample of young people. Although the present study provides us with interesting information about age-related changes in awareness of gender inequalities, we are conscious that its cross-sectional design has drawbacks for those concerned with the development of the awareness of gender inequalities. Since we compared different groups of students at different school levels, we cannot be certain that the observed differences are not related to a cohort effect. Studies using a longitudinal design would complete our findings by controlling for individual differences. Our second limitation relates to the generalizability of the findings. The present study was conducted only among French students. However, gender inequalities in education and the professional world can vary greatly across countries (OECD 2016; WEF 2018). Studies need to be conducted among students from different nations to assess the generalizability of our findings. Actual gender inequalities in education and professional world might influence young people's perceptions. Future research could replicate the present study in more (e.g., Iceland) or less (e.g., Spain) egalitarian countries and in nations where gender differences in education are larger (e.g., Finland) or smaller (e.g., The Netherlands) than they are in France (OECD 
2016; WEF 2018). Finally, in the present study, we investigated status as defined by Tajfel and Turner (1979) and Sachdev and Bourhis (1987), that is, as the outcome of social comparison which reflects the relative position of a group on a valued dimension of comparison in a specific context. For this reason, we investigated students' perception of boys' and girls' status in the academic and occupational contexts by asking students to position these groups on a valued dimension of comparison within each of these contexts, respectively grades and income. As our operationalization corresponds to a context-specific definition of status, future research may also be needed to understand how gender status is perceived in general, i.e., in terms of social respect, recognition, importance and prestige (Fiske 2010).

\section{Conclusion}

The present study is one of the few that have examined the young people's perceptions of gender inequalities. It is, to our knowledge, the first study to investigate awareness of a reversal in gender status between the academic and occupational contexts. The perception of such a reversal could have important implications for students and these implications might be different for female and male students. On the one hand, female students seem to know that, even though they can be considered as academically superior to male students, they still have a lower status than men in the professional world. Therefore, female students might consider academic achievement as necessary but not sufficient to improve their ingroup status in adulthood. On the other hand, male students are likely to believe that they will benefit from the reversal of gender inequalities in achievement. Male students appear to be aware that, even though girls are academically superior to them, they will enjoy a higher social status than women. This could lead them to think that they do not need to be as academically successful as girls to succeed in later life. This assumption is supported by the nonsignificant correlations between the boys' group' perceived competence and their academic status, irrespective of the participants' academic level. In line with this idea, some studies have shown that boys are less engaged than girls are at school (Wang and Eccles 2012). Boys engage in more disruptive behaviors, have less positive attitudes towards academic work and spend less time doing their homework (Jones and Myhill 2004; OECD 2015; Van Houtte 2004). King (2016) showed that boys exhibit higher levels of work avoidance and emotional and behavioral disaffection than girls (King 2016). Interestingly, boys also appeared to endorse less social status goals than girls do, meaning that they are less likely to consider that academic achievement will help them achieve a higher status in later life. As the awareness of a reversal in gender gaps might potentially have multiple repercussions, future studies could investigate its causes and consequences for students' educational and life experience. These studies could explore more closely whether, and how, female and male students perceive that academic and occupational success are related. Understanding how young people justify the paradox between girls' academic success and men's domination in the professional world might help us understand how it persists 
or is likely to change. Perceiving female students as a non-traditional female subgroup could have particularly important implications for maintaining gender hierarchy. 


\section{Compliance with ethical standards}

Conflict of interest. The authors declare that they have no conflicts of interest.

Ethical approval. The ethics committee for the protection of persons (CPP 2017 / CE 29, IRB00008526) approved the study.

Informed consent. Informed consent was obtained from all participants and their parents (for those who they were under $18)$.

\section{Data transparency}

The dataset for the present study can be found on the Open Science Framework (https://osf.io/cx2rh/). Study material (in French language) is available upon request from the corresponding authors. 


\section{Author biographies}

Alyson Sicard is a post-doctoral researcher at the University Clermont Auvergne as part of the DISESTEEM project, and a member of the LASPCO (Laboratoire de Psychologie Sociale et Cognitive). Her research interests include gender inequalities and the consequences of threatening academic contexts.

Delphine Martinot is a Professor of Social Psychology in the Laboratoire de Psychologie Sociale et Cognitive UMR CNRS 6024 of University Clermont Auvergne. Her research focuses on gender stereotypes, school achievement, and academic disengagement. She studies how to decrease academic inequalities, especially among female and male pupils and students.

Marie-Christine Toczek is a Professor of Educational Sciences in the Laboratoire Activité Connaissance Transmission Education of University Clermont Auvergne. Her research focuses on pupils/students assessment, teaching methods and more currently, on the role of behavioral engagement and mastery goals in blended-learning in higher education.

Julie Pironom is an Engineer Statistician in the Laboratoire Activité Connaissance Transmission Education of University Clermont Auvergne. She works on the different statistical aspects of the research unit (analyzes, questionnaire conception and validation). She takes part in research in the field of education and sports sciences.

Céline Darnon is a professor of social psychology at Université Clermont Auvergne, France. Her research examines how the educational system, because of the values and the goals it promotes, contribute to legitimate and reproduce class and gender inequalities. 


\section{References}

Aelenei, C., Martinot, D., Sicard, A., \& Darnon, C. (2019). When an academic culture based on self-enhancement values undermines female students' sense of belonging, self-efficacy, and academic choices. Journal Of Social Psychology.

Bourdieu, P. (1998). La Domination Masculine (Le Seuil.). Paris.

Buchmann, C., DiPrete, T. a., \& McDaniel, A. (2008). Gender Inequalities in Education. Annual Review of Sociology, 34(1), 319-337. https://doi.org/10.1146/annurev.soc.34.040507.134719

Cambon, L., Yzerbyt, V., \& Yakimova, S. (2015). Compensation in intergroup relations: An investigation of its structural and strategic foundations. British Journal of Social Psychology, 54(1), 140-158. https://doi.org/10.1111/bjso.12067

Cuddy, A. J. C., Fiske, S. T., \& Glick, P. (2008). Warmth and Competence as Universal Dimensions of Social Perception: The Stereotype Content Model and the BIAS Map. Advances in Experimental Social Psychology, 40, 61-149. https://doi.org/10.1016/S0065-2601(07)00002-0

Cuddy, A. J. C., Fiske, S. T., Kwan, V. S. Y., Glick, P., Demoulin, S., Leyens, J. P., et al. (2009). Stereotype content model across cultures: Towards universal similarities and some differences. British Journal of Social Psychology, 48(1), 1-33. https://doi.org/10.1348/014466608X314935

DEPP. (2018). Filles et garçons sur le chemin de l'égalité, de l'école à l'enseignement supérieur. https://doi.org/10.3917/empa.053.0033

Duckworth, A. L., \& Seligman, M. E. P. (2006). Self-discipline gives girls the edge: Gender in self-discipline, grades, and achievement test scores. Journal of Educational Psychology, 98(1), 198-208. https://doi.org/10.1037/00220663.98.1.198

Eagly, A. H., Nater, C., Miller, D. I., Kaufmann, M., \& Sczesny, S. (2019). Gender stereotypes have changed: A crosstemporal meta-analysis of U.S. public opinion polls from 1946 to 2018. American Psychologist. https://doi.org/10.1037/amp0000494

Eckes, T. (2002). Paternalistic and Envious Gender Stereotypes: Testing Predictions From the Stereotype Content Model. Sex Roles, 47(3/4). https://link-springercom.login.ezproxy.library.ualberta.ca/content/pdf/10.1023\%2FA\%3A1021020920715.pdf

European Institute for Gender Equality. (2017). Gender Equality Index 2017: Methodological Report. https://doi.org/10.2839/9948

EURYDICE. (2010). Différences entre les genres en matière de réussite scolaire: étude sur les mesures prises et la 


\section{RUNNING HEAD: STUDENTS’ AWARENESS OF A REVERSAL IN GENDER STATUS}

situation actuelle en Europe. Bruxelles. https://doi.org/10.2797/36004

Fiske, E. B. (2012). World Altas of Gender Equality in Education. UNESCO. Paris, France. https://doi.org/10.15220/97892-3-104232-4-en

Fiske, S. (2010). Interpersonal Stratification: Power Status and Subordination. In S. T. Fiske, D. T. Gilbert, \& G. Lindzey (Eds.), Handbook of social psychology (pp. 941-982). John Wiley \& Sons.

Fiske, S. T., Cuddy, A. J. C., Glick, P., \& Xu, J. (2002). A model of (often mixed) stereotype content: Competence and warmth respectively follow from perceived status and competition. Journal of Personality and Social Psychology, 82(6), 878-902. https://doi.org/10.1037/0022-3514.82.6.878

Glick, P., \& Fiske, S. T. (2001). An ambivalent alliance: Hostile and benevolent sexism as complementary justifications for gender inequality. American Psychologist, 56(2), 109-118. https://doi.org/10.1037/0003-066X.56.2.109

Hartley, B. L., \& Sutton, R. M. (2013). A stereotype threat account of boys' academic underachievement. Child Development, 84(5), 1716-1733. https://doi.org/10.1111/cdev.12079

Heyder, A., \& Kessels, U. (2013). Is School Feminine? Implicit Gender Stereotyping of School as a Predictor of Academic Achievement. Sex Roles, 69(11-12), 605-617. https://doi.org/10.1007/s11199-013-0309-9

Jones, S., \& Myhill, D. (2004). ‘Troublesome boys' and 'compliant girls': gender identity and perceptions of achievement and underachievement. British Journal of Sociology of Education, 25(5), 547-561.

https://doi.org/10.1080/0142569042000252044

Kay, A. C., Gaucher, D., Peach, J. M., Laurin, K., Friesen, J., Zanna, M. P., \& Spencer, S. J. (2009). Inequality, discrimination, and the power of the status quo: Direct evidence for a motivation to see the way things are as the way they should be. Journal of Personality and Social Psychology, 97(3), 421-434.

https://doi.org/10.1037/a0015997

Kenney-Benson, G. A., Pomerantz, E. M., Ryan, A. M., \& Patrick, H. (2006). Sex differences in math performance: The role of children's approach to schoolwork. Developmental Psychology, 42(1), 11-26. https://doi.org/10.1037/00121649.42.1.11

Kervyn, N., Yzerbyt, V., \& Judd, C. M. (2010). Compensation between warmth and competence: Antecedents and consequences of a negative relation between the two fundamental dimensions of social perception. European Review of Social Psychology, 21(1), 155-187. https://doi.org/10.1080/13546805.2010.517997

King, R. B. (2016). Gender differences in motivation, engagement and achievement are related to students' perceptions of peer-but not of parent or teacher-attitudes toward school. Learning and Individual Differences, 52, 60-71. https://doi.org/10.1016/j.lindif.2016.10.006 
Kraus, M. W., \& Stephens, N. M. (2012). A road map for an emerging psychology of social class. Social and Personality Psychology Compass, 6(9), 642-656. https://doi.org/10.1111/j.1751-9004.2012.00453.x

Latsch, M., \& Hannover, B. (2014). Smart girls, dumb boys!?: How the discourse on "Failing Boys" Impacts Performances and Motivational Goal Orientation in German School Students. Social Psychology, 45(2), 112-126. https://doi.org/10.1027/1864-9335/a000167

Leaper, C., \& Brown, C. S. (2014). Sexism in Schools. In L. S. Liben \& R. S. Bigler (Eds.), Advances in Child Development and Behavior. The role of gender in educational contexts and outcomes (1st ed., Vol. 47, pp. 189223). Elsevier Inc. https://doi.org/10.1016/bs.acdb.2014.04.001

Liben, L. S., Bigler, R. S., \& Krogh, H. R. (2001). Pink and Blue Collar Jobs: Children’s Judgments of Job Status and Job Aspirations in Relation to Sex of Worker. Journal of Experimental Child Psychology, 79(4), 346-363. https://doi.org/10.1006/jecp.2000.2611

Martin, C. L., \& Ruble, D. N. (2010). Patterns of Gender Development. Annual Review of Psychology, 61(1), 353-381. https://doi.org/10.1146/annurev.psych.093008.100511

Martinot, D., Bagès, C., \& Désert, M. (2012). French Children's Awareness of Gender Stereotypes About Mathematics and Reading: When Girls Improve Their Reputation in Math. Sex Roles, 66(3-4), 210-219. https://doi.org/10.1007/s11199-011-0032-3

McFarland, J., Cui, J., \& Stark, P. (2018). Trends in High School Dropout and Completion Rates in the United States: 2014. https://nces.ed.gov/pubs2018/2018117.pdf

MESRI. (2018). Vers l'Égalité Femmes -Hommes? Chiffres clés. http://www.enseignementsuprecherche.gouv.fr/cid127382/esri-chiffres-cles-de-1-egalite-femmes-hommes.html

Meyer, M., Cimpian, A., \& Leslie, S.-J. (2015). Women are underrepresented in fields where success is believed to require brilliance. Frontiers in Psychology, 6, 1-12. https://doi.org/10.3389/fpsyg.2015.00235

Neff, K. D., Cooper, C. E., \& Woodruff, A. L. (2007). Children's and adolescents' developing perceptions of gender inequality. Social Development, 16(4), 682-699. https://doi.org/10.1111/j.1467-9507.2007.00411.x

OECD. (2013). PISA 2012 Results: Ready to Learn (Volume III). https://doi.org/10.1787/9789264201170-en

OECD. (2015). The ABC of Gender Equality in Education. OECD Publishing. https://doi.org/10.1787/9789264229945en

OECD. (2016). PISA 2015 Results (Volume I): Excellence and Equity in Education. Paris: PISA, OECD Publishing. https://doi.org/http://dx.doi.org/10.1787/9789264266490-en

OECD. (2017). Education at a Glance 2017: OECD Indicators. Paris: OECD Publishing. 


\section{RUNNING HEAD: STUDENTS’ AWARENESS OF A REVERSAL IN GENDER STATUS}

https://doi.org/http://dx.doi.org/10.1787/eag-2017-en

Pomerantz, E. M., Altermatt, E. R., \& Saxon, J. L. (2002). Making the grade but feeling distressed: Gender differences in academic performance and internal distress. Journal of Educational Psychology, 94(2), 396-404. https://doi.org/10.1037/0022-0663.94.2.396

Sachdev, I., \& Bourhis, R. Y. (1987). Status differenttals and intergroup behaviour. European Journal of Social Psychology, 17(3), 277-293. https://doi.org/10.1002/ejsp.2420170304

Sweeting, H., West, P., Young, R., \& Kelly, S. (2011). Dimensions of adolescent subjective social status within the school community: Description and correlates. Journal of Adolescence, 34(3), 493-504.

https://doi.org/10.1016/j.adolescence.2010.06.001

Tajfel, H., \& Turner, J. C. (1979). An Integrative Theory of Intergroup Conflict. In W. G. Austin \& S. Worchel (Eds.), The Social Psychology of Intergroup Relations (pp. 56-65). Monterey, CA: Brooks-Cole. https://doi.org/10.1016/S0065-2601(05)37005-5

Teig, S., \& Susskind, J. E. (2008). Truck driver or nurse? the impact of gender roles and occupational status on children's occupational preferences. Sex Roles, 58(11-12), 848-863. https://doi.org/10.1007/s11199-008-9410-x

United Nations. (2015). World's Women 2015: Trends and Statistics. https://unstats.un.org/unsd/gender/aboutWW2015.html

Van Houtte, M. (2004). Why boys achieve less at school than girls: the difference between boys' and girls' academic culture. Educational Studies, 30(2), 159-173. https://doi.org/10.1080/0305569032000159804

Verniers, C., \& Martinot, D. (2015a). Perception of students' intelligence malleability and potential for future success: Unfavourable beliefs towards girls. British Journal of Educational Psychology, 85(3), 289-299. https://doi.org/10.1111/bjep.12073

Verniers, C., \& Martinot, D. (2015b). Characteristics expected in fields of higher education and gender stereotypical traits related to academic success: a mirror effect. Social Psychology of Education, 18(4), 719-733. https://doi.org/10.1007/s11218-015-9312-z

Verniers, C., Martinot, D., \& Dompnier, B. (2016). The feminization of school hypothesis called into question among junior and high school students. British Journal of Educational Psychology, 86(3), 369-381.

https://doi.org/10.1111/bjep.12111

Voyer, D., \& Voyer, S. D. (2014). Psychological Bulletin Gender Differences in Scholastic Achievement : A Gender Differences in Scholastic Achievement : A Meta-Analysis. Psychological Bulletin, 140(4), 1174- 1204. https://doi.org/10.1037/a0036620 
Wang, M. Te, \& Eccles, J. S. (2012). Social Support Matters: Longitudinal Effects of Social Support on Three Dimensions of School Engagement From Middle to High School. Child Development, 83(3), 877-895. https://doi.org/10.1111/j.1467-8624.2012.01745.x

Weaver-Hightower, M. (2003). The "Boy Turn" in Research on Gender and Education. Review of Educational Research, 73(4), 471-498. https://doi.org/10.3102/00346543073004471

WEF. (2017). The Global Gender Gap Report 2017. World Economic Forum. https://www.weforum.org/reports/theglobal-gender-gap-report-2017

WEF. (2018). The Global Gender Gap Report 2018. World Economic Forum (Vol. 25). https://doi.org/10.1177/0192513X04267098

Yzerbyt, V., Provost, V., \& Corneille, O. (2005). Not competent but warm... Really? Compensatory stereotypes in the French-speaking world. Group Processes and Intergroup Relations, 8(3), 291-308.

https://doi.org/10.1177/1368430205053944 
Table 1. Description of the study sample.

\begin{tabular}{|c|c|c|c|c|c|c|c|c|c|}
\hline & & \multirow{2}{*}{$\begin{array}{c}\text { Age } \\
\text { (mean) }\end{array}$} & \multicolumn{3}{|c|}{ Gender } & \multicolumn{3}{|c|}{ Socio-economic status } & \multirow{2}{*}{ Total } \\
\hline & & & Boys & Girls & Missing & High & Low & Missing & \\
\hline Middle & $6^{\text {th }}$ grade & 10.99 & 50 & 50 & 0 & 79 & 16 & 5 & 100 \\
\hline school & $8^{\text {th }}$ grade & 12.97 & 47 & 70 & 0 & 83 & 31 & 3 & 117 \\
\hline \multirow{2}{*}{ High school } & $10^{\text {th }}$ grade & 15.17 & 52 & 54 & 0 & 60 & 45 & 1 & 106 \\
\hline & $12^{\text {th }}$ grade & 17.04 & 44 & 70 & 0 & 77 & 37 & 0 & 114 \\
\hline University & $\begin{array}{l}2^{\text {nd }} \text { year of } \\
\text { bachelor's degree }\end{array}$ & 20.04 & 97 & 103 & 1 & 130 & 69 & 2 & 201 \\
\hline \multicolumn{2}{|c|}{ Overall sample } & 15.98 & 290 & 347 & 1 & 429 & 198 & 11 & 638 \\
\hline
\end{tabular}


Table 2. Simple effects of target group on perceived status depending on target context and participants' school level.

\begin{tabular}{|c|c|c|c|c|c|c|}
\hline & Target context & $\begin{array}{l}\text { Estimated mean for } \\
\text { girls group's status }\end{array}$ & $\begin{array}{l}\text { Estimated mean for } \\
\text { boys group's status }\end{array}$ & $\mathrm{F}$ & $\mathrm{p}$ & $\eta_{p}^{2}$ \\
\hline \multirow{4}{*}{$6^{\text {th }}$ grade } & Middle school & 7.91 & 7.21 & 6.75 & .010 & .011 \\
\hline & High school & 7.47 & 6.78 & 6.95 & .009 & .011 \\
\hline & University & 8.08 & 7.44 & 4.40 & .036 & .007 \\
\hline & Professional world & 8.28 & 7.68 & 4.27 & .039 & .007 \\
\hline \multirow{4}{*}{$8^{\text {th }}$ grade } & Middle school & 7.66 & 7.00 & 6.67 & .010 & .011 \\
\hline & High school & 7.49 & 6.49 & 16.27 & .000 & .026 \\
\hline & University & 7.76 & 7.20 & 3.71 & .055 & .006 \\
\hline & Professional world & 7.29 & 7.95 & 5.70 & .017 & .009 \\
\hline \multirow{4}{*}{$10^{\text {th }}$ grade } & Middle school & 8.17 & 7.02 & 18.72 & .000 & .030 \\
\hline & High school & 7.81 & 7.01 & 9.68 & .002 & .016 \\
\hline & University & 8.00 & 7.38 & 4.39 & .037 & .007 \\
\hline & Professional world & 6.94 & 8.31 & 23.09 & .000 & .037 \\
\hline \multirow{4}{*}{$12^{\text {th }}$ grade } & Middle school & 8.13 & 7.13 & 14.14 & .000 & .023 \\
\hline & High school & 7.79 & 6.68 & 19.02 & .000 & .030 \\
\hline & University & 7.33 & 6.88 & 2.26 & .133 & .004 \\
\hline & Professional world & 6.29 & 7.73 & 25.73 & .000 & .041 \\
\hline \multirow{4}{*}{$\begin{array}{c}2^{\text {nd }} \text { year of } \\
\text { bachelor's degree }\end{array}$} & Middle school & 7.98 & 7.11 & 20.83 & .000 & .036 \\
\hline & High school & 7.78 & 6.89 & 22.91 & .000 & .036 \\
\hline & University & 7.68 & 6.23 & 44.70 & .000 & .069 \\
\hline & Professional world & 6.60 & 7.73 & 29.87 & .000 & .047 \\
\hline
\end{tabular}


Table 3. Simple effects of target group on perceived status depending on target context, participants' gender and school level.

\begin{tabular}{|c|c|c|c|c|c|c|c|}
\hline & \multirow{2}{*}{ Target context } & \multicolumn{3}{|c|}{ Male participants } & \multicolumn{3}{|c|}{ Female participants } \\
\hline & & $\mathrm{F}$ & $\mathrm{p}$ & $\eta_{p}^{2}$ & $\mathrm{~F}$ & $\mathrm{p}$ & $\eta_{p}^{2}$ \\
\hline \multirow{4}{*}{$6^{\text {th }}$ grade } & Middle school & 1.10 & .296 & .002 & 6.85 & .009 & .011 \\
\hline & High school & 5.14 & .024 & .008 & 2.16 & .143 & .004 \\
\hline & University & 9.07 & .003 & .015 & 0.01 & .978 & .000 \\
\hline & Professional world & 1.65 & .200 & .003 & 2.68 & .103 & .004 \\
\hline \multirow{4}{*}{$8^{\text {th }}$ grade } & Middle school & 1.49 & .223 & .002 & 6.71 & .010 & .011 \\
\hline & High school & 6.55 & .011 & .011 & 10.52 & .001 & .017 \\
\hline & University & 3.16 & .076 & .005 & 0.76 & .385 & .001 \\
\hline & Professional world & 2.33 & .127 & .004 & 3.63 & .057 & .006 \\
\hline \multirow{4}{*}{$10^{\text {th }}$ grade } & Middle school & 3.16 & .076 & .005 & 19.54 & .000 & .031 \\
\hline & High school & 3.40 & .066 & .006 & 6.68 & .010 & .011 \\
\hline & University & 3.30 & .070 & .005 & 1.27 & .260 & .002 \\
\hline & Professional world & 13.07 & .000 & .021 & 10.06 & .002 & .016 \\
\hline \multirow{4}{*}{$12^{\text {th }}$ grade } & Middle school & 1.29 & .257 & .002 & 21.83 & .000 & .035 \\
\hline & High school & 6.98 & .008 & .011 & 13.77 & .000 & .022 \\
\hline & University & 2.58 & .109 & .004 & 0.15 & .702 & .000 \\
\hline & Professional world & 2.31 & .129 & .004 & 39.86 & .000 & .062 \\
\hline \multirow{4}{*}{$\begin{array}{c}2^{\text {nd }} \text { year of } \\
\text { bachelor's degree }\end{array}$} & Middle school & 0.16 & .693 & .000 & 38.03 & .000 & .059 \\
\hline & High school & 0.26 & .614 & .000 & 40.63 & .000 & .063 \\
\hline & University & 22.48 & .000 & .063 & 22.23 & .000 & .035 \\
\hline & Professional world & 6.81 & .009 & .011 & 26.71 & .000 & .042 \\
\hline
\end{tabular}


Table 4. Simple effects of target group on undergraduates perception of status depending on target context and students' study field

\begin{tabular}{|c|c|c|c|c|c|c|c|c|c|c|}
\hline \multirow{2}{*}{ Target context } & \multicolumn{5}{|c|}{ Biology students } & \multicolumn{5}{|c|}{ Sport students } \\
\hline & Moys & $M_{\text {girls }}$ & $\mathrm{F}$ & $\mathrm{p}$ & $\eta_{p}^{2}$ & $M_{\text {Boys }}$ & Mgirls & $\mathrm{F}$ & $\mathrm{p}$ & $\eta_{p}^{2}$ \\
\hline Middle school & 6.90 & 8.39 & 26.44 & .000 & .122 & 7.25 & 7.81 & 5.05 & .026 & .026 \\
\hline High school & 6.83 & 8.11 & 20.01 & .000 & .095 & 6.84 & 7.61 & 10.05 & .002 & .050 \\
\hline University & 6.60 & 7.75 & 14.19 & .000 & .069 & 5.86 & 7.68 & 48.69 & .000 & .204 \\
\hline Professional world & 7.87 & 6.62 & 14.78 & .000 & .072 & 7.58 & 6.68 & 10.49 & .001 & .052 \\
\hline
\end{tabular}


RUNNING HEAD: STUDENTS' AWARENESS OF A REVERSAL IN GENDER STATUS

Table 5. Simple effects of target group on perceived competence and warmth depending on participants' school level

\begin{tabular}{|c|c|c|c|c|c|c|c|c|c|c|}
\hline \multirow{2}{*}{ Participants' school level } & \multicolumn{5}{|c|}{ Competence } & \multicolumn{5}{|c|}{ Warmth } \\
\hline & $M_{\text {Boys }}$ & $\mathrm{M}_{\text {girls }}$ & $\mathrm{F}$ & $\mathrm{p}$ & $\eta_{p^{2}}^{2}$ & $M_{\text {Boys }}$ & $M_{\text {girls }}$ & $\mathrm{F}$ & $\mathrm{p}$ & $\eta_{p}^{2}$ \\
\hline Sixth grade & 5.26 & 5.78 & 10.19 & .001 & .016 & 4.13 & 4.72 & 7.64 & .006 & .012 \\
\hline Eighth grade & 5.25 & 5.70 & 8.48 & .004 & .014 & 3.99 & 4.65 & 10.50 & .001 & .017 \\
\hline Tenth grade & 5.40 & 5.91 & 10.49 & .001 & 017 & 4.76 & 4.81 & 0.07 & .795 & .000 \\
\hline Twelfth grade & 5.18 & 6.10 & 34.37 & .000 & .053 & 4.54 & 4.77 & 1.23 & .267 & .002 \\
\hline Undergraduate & 5.16 & 5.89 & 41.13 & .000 & .063 & 4.90 & 4.84 & 0.13 & .716 & .000 \\
\hline
\end{tabular}


Table 6. Bivariate correlations between the different dependent variables.

\begin{tabular}{|c|c|c|c|c|c|c|}
\hline & 1 & 2 & 3 & 4 & 5 & 6 \\
\hline 1. Middle school status & & $.40 * *$ & .04 & .08 & .07 & .05 \\
\hline 2.High-school status & $.66 * *$ & & $.36 * *$ & $.24 * *$ & .09 & .07 \\
\hline 3.University status & $.40 * *$ & $.58 * *$ & & $.43 * *$ & .07 & .10 \\
\hline 4.Professional status & $.14 * *$ & $.18 * *$ & $.36 * *$ & & $.13 *$ & $.16^{* *}$ \\
\hline 5.Competence & $.24 * *$ & $.18 * *$ & $.11 *$ & $.17 * *$ & & $.42 * *$ \\
\hline 6.Warmth & $.33 * *$ & $.34 * *$ & $.16^{*}$ & .09 & $.52 * *$ & \\
\hline
\end{tabular}

Notes. Correlations for the boys' group $(\mathrm{N}=313)$ are reported above the diagonal whereas correlations for the girls' group $(\mathrm{N}=320)$ are reported below the diagonal.

$* \mathrm{p}<.05, * * \mathrm{p}<.01$. 


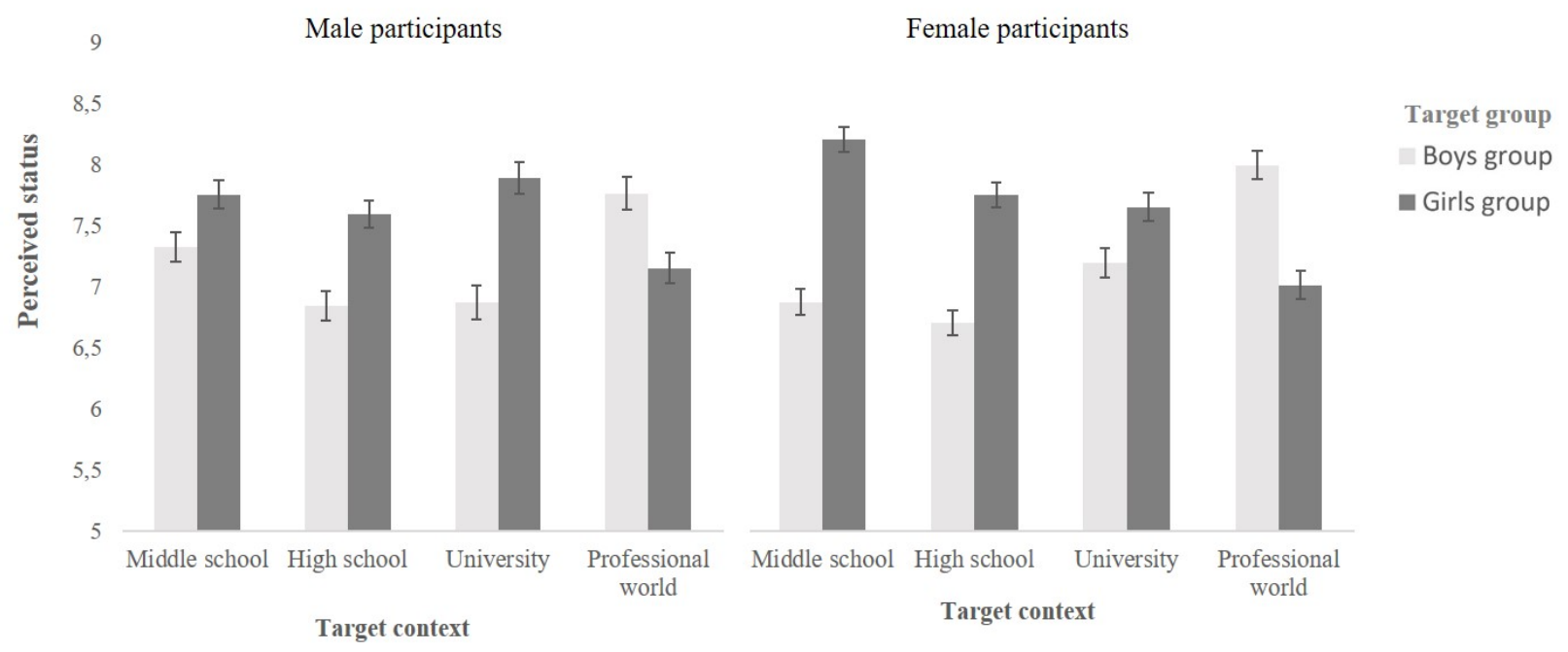

Fig 1. Male and female participants' perceptions of the status of the boys and girls groups. Error bars denote the standard errors of estimated means. 


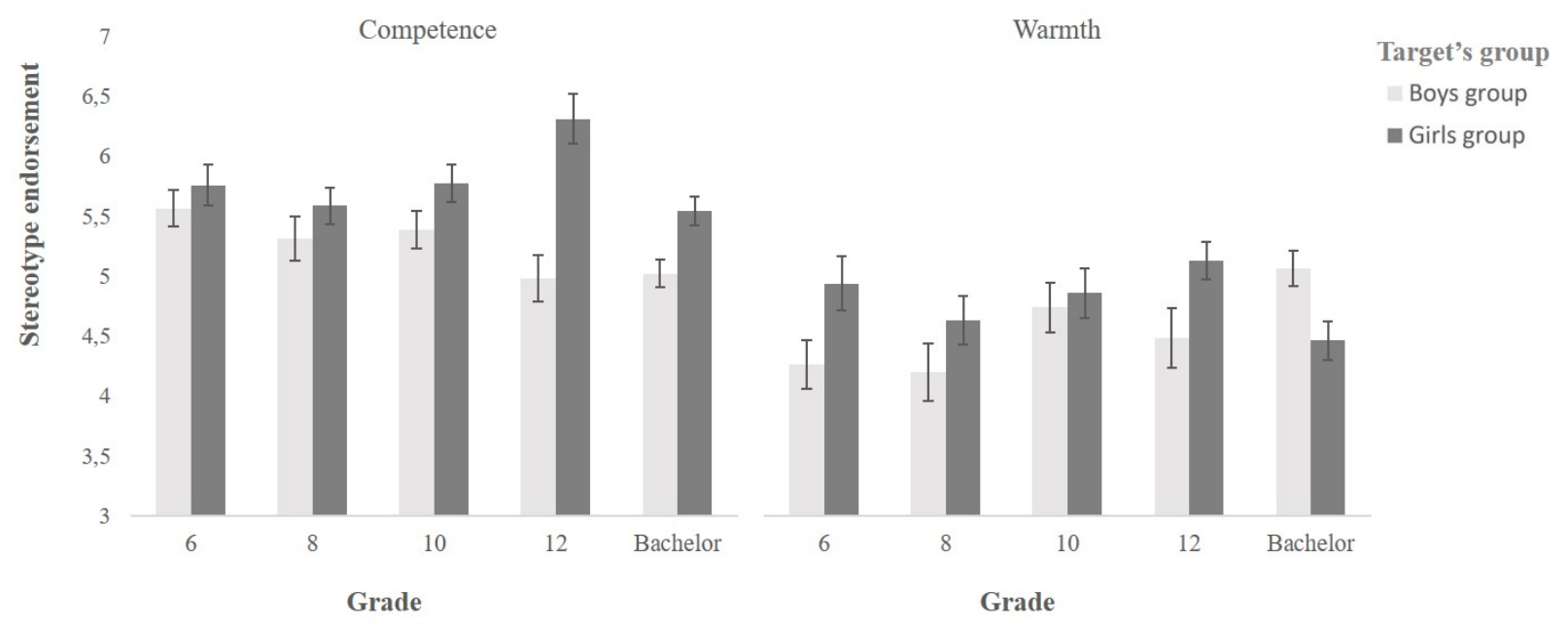

Fig 2a. Male participants' perceptions of the characteristics of the boys' and girls' groups. Error bars denote the standard errors of estimated means. 


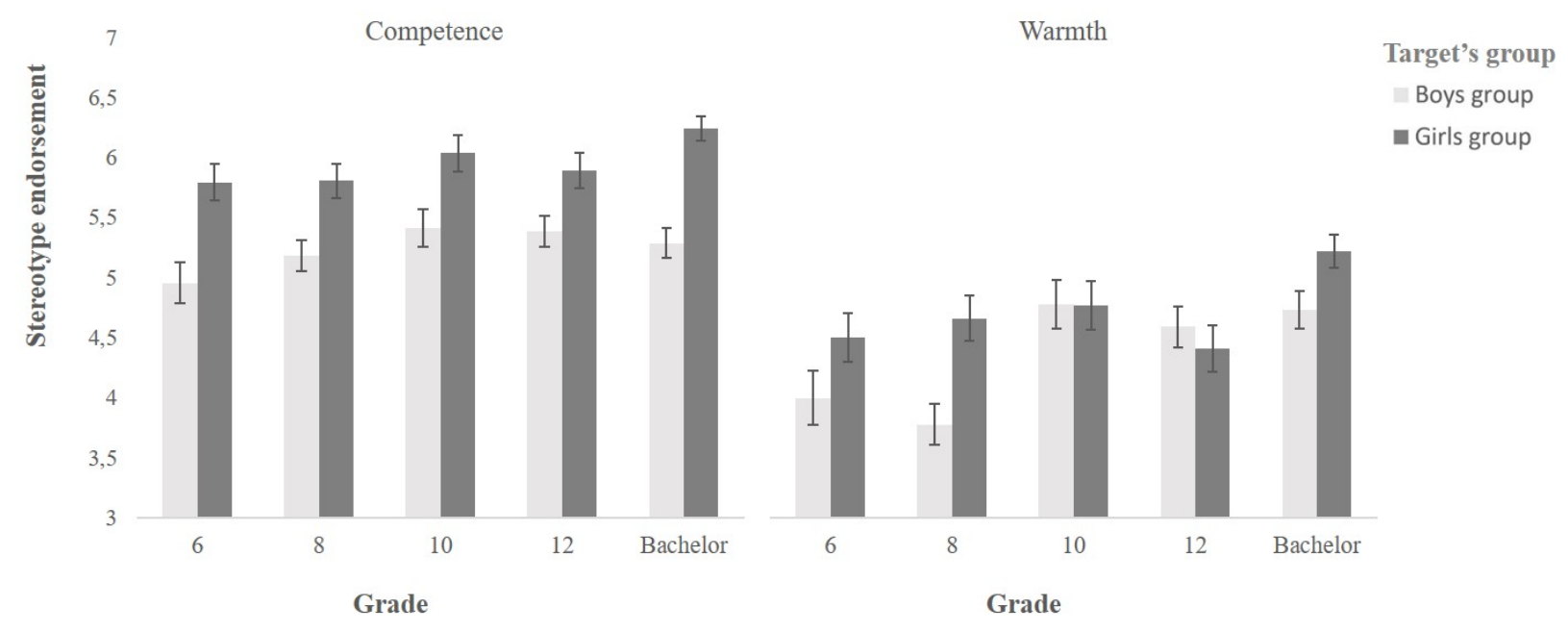

Fig 2b. Female participants' perceptions of the characteristics of the boys' and girls' groups. Error bars denote the standard errors of estimated means. 